\title{
Management Status and Development Strategy of Financial Management in Electric Power Enterprises
}

\author{
Liao Lizhen \\ North China Electric Power University \\ Beijing, China
}

\begin{abstract}
As the basic industry of the national economy, electric power enterprises have an important impact on the sustainable development of Chinese economy. Financial management, a complex and tedious project, plays a very important role in the daily work of electric power enterprises. Mainly starting from the current situation of financial management in electric power enterprises, by analyzing the problems existing in Chinese power enterprises, this paper puts forward corresponding development strategies to promote sustained and stable development of electric power enterprises.
\end{abstract}

Keywords -electric power enterprises; financial management; current situation; countermeasures

\section{INTRODUCTION}

Electric power enterprise is an important sector of our national economy, playing an irreplaceable role in the development of national economy. With the rapid development of market economy, Chinese electric power system is undergoing constant reform, and has gradually become an economy that is self-restraint, self-development, self-improvement, and self-management and self-financing economies. As the country gradually liberalized the electricity industry, the influx of all kinds of social capital into the electric power industry has brought a great impact to the power enterprises. If the power companies want to maintain their own advantages in the industry, it needs to improve its profitability, solvency and operational capacity in order to maintain and increase the value of capital. It can be seen that it has great practical significance to strengthen the financial management of enterprises at this stage.

\section{OVERVIEW OF FINANCE MANAGEMENT IN AN} ENTERPRISE

\section{A. Definition of finance management in an enterprise}

Financial management of enterprises refers to an organized management of the financial activities and financial relations of an enterprise under the guidance of national laws, regulations, guidelines and policies, in accordance with the objective laws of national economic development and the requirements of the enterprise for capital management, which is an important part of enterprise production and operation management. Enterprise financial management is a financial activity to raise funds. invest funds and supervise control it, focusing on the business objectives of maximizing profits and minimizing risks. The level of financial management in Enterprises is directly related to the survival and development of enterprises in the future.

\section{B. Target of finance management in an enterprise}

Financial management objectives of enterprises is the fundamental purpose of the organization's financial activities and financial relations, which determines the basic direction of enterprise financial management, and is the starting point of enterprise financial management. Under the circumstances of socialist market economy, as a profit making organization, enterprises should strive for maximizing profits and shoulder social responsibilities, taking into account the interests of other parties and strives to maximize financial results, optimize the financial situation and effectively allocate resources.

III. CURRENT SITUATION AND PROBLEMS OF FINANCIAL MANAGEMENT IN ELECTRIC POWER ENTERPRISES IN CHINA

\section{A. Weak sense of financial management in Enterprises}

With the further development of market-oriented reform of electric power system, the electricity market is becoming increasingly fierce. Because the level of financial management directly affects the level of enterprise management, which further affects the long and long term economic benefits of enterprises, enterprises must attach importance to enterprise management if they want to survive and develop. Therefore, it has an undeniable important role in promoting the long-term development of enterprises to attach importance to enterprise financial management and excavate various functions of financial management. And for a long time, China's power enterprises have been monopolized. Influenced by the planned economic system and the characteristics of the industry, it makes the electric power enterprises always attach importance to production and safety rather than operation and profit [1] financial management system construction is not perfect. Management has weak sense of financial management and has not given enough attention to financial management. Management activities to enterprises are limited to production and operation activities, ignoring the management of financial activities. And this phenomenon is not only in the 
management, but also in the corporate employees. Most of the company's scientific research personnel, production personnel and other employees believe that the financial management department of the power company can only reflect the value when reimbursing the expenses. The financial management personnel usually do not work, just sitting in the office to do other things that are not related to financial management work. The financial management department is dispensable in the organizational structure of the enterprise. The management of the power company has invested a large amount of money in the scientific research department so that it spends a lot of money to hire scientific researchers, and the requirements for the appointment of personnel in the financial management department are not strict, therefore, the requirements for financial management personnel are far from the overall requirements of the power companies and it does not match the position of power companies in many companies.

\section{B. The imperfection of financial management system construction}

At present, the budget management of electric power enterprises is unreasonable, while there is a certain degree of derailment of financial budgeting to reality. As a general electric power enterprise adopts the procedure of making up and down and reporting step by step, information is passed on layer by layer. The speed of information transmission cannot keep pace with the development of power enterprises, resulting in budget lag. Without strict budget management examination, the budget execution power of electric power enterprises is not enough. Due to lacking of competition for a long time, power enterprises have been under constant control in financial management, The shortage and backlog of the procurement and storage of some materials lack corresponding financial treatment. Some of the power companies have a serious "the only big shareholder" phenomenon in their ownership structure. Senior executives abuse their power for personal gain and exceed their powers, without scientific and sound internal control system. The financial incentive and restraint mechanism of electric power enterprises is imperfect. The manager responsibility system has been implemented for a long time in electric power enterprises in China, and managers of power companies tend to invest in "research with little investment but quick result" research and development projects rather than long-term efficient investment projects. Chinese capital market is developing slowly, while the marketization of power factor market and product market is relatively low. Coupled with the particularity of power products, it makes managers of electric power enterprises without risk liability.[2] On the one hand, it keeps the managers of electric power enterprises in the high position for a long time, neither arousing the enthusiasm of managers nor encouraging other employees. On the other hand, the low marketization and the characteristics of the power industry make the market not play its due role in restraint and resource optimization. The financial incentive and restraint mechanism of electric power enterprises is imperfect. The financial and financial management accounting of electric power enterprises started earlier, which is in the process of transformation from accounting to financial management analysis. Duplication of software applications is serious, information utilization and integration rate is not high, and information sharing is relatively low.

\section{Lack of outstanding talents in financial management department}

Because it has been in a relatively closed state of management for a long time, the scientific modern financial management system is not included in the effective management mechanism of the electric power enterprises in our country. Moreover, Chinese power enterprises pay little attention to the cultivation of high-quality financial management personnel, which makes financial managers no longer adapt to the development needs of the current power enterprises.[3] In addition, the demand of financial managers in power enterprises is greater than that of supply. Due to the particularity of power enterprises, the requirements of power enterprises for financial management personnel are different from those of general enterprises in financial management. Meanwhile, in China, there are fewer colleges and universities specializing in the training of financial accounting for electric power enterprises than those specializing in other types of enterprises. Most of the financial management departments recruited by electric power companies are not from electric power universities, whose knowledge about financial accounting in the power industry is relatively small, and the foundation is relatively weak. Meanwhile, without the awareness of keeping pace with the times, the existing financial management personnel of electric power enterprises hold the idea of enterprise financial management before the reform of electric power enterprise system, who do not combine their responsibilities with the requirements of the times, and have not yet been able to integrate financial management with big data. On the other hand, due to the longterm presence of financial management personnel in power companies, the contact with the outside world is not dense, and there is no close pace with the times. Moreover, due to the particularity of power companies, the financial management departments of power companies do not have strict personnel elimination systems, as long as financial management Department staff do not make particularly serious mistakes or take the initiative to leave, they can stay in this position until retirement. It is also for this reason that most of the financial management departments of power companies relax their own requirements after taking office, which is limited to the daily work, resulting in the stagnation of financial managers' own literacy or even retrogression. At present, big data is developing rapidly. The financial management staffs of power companies do not actively learn it for lacking the conscious and motivation of the corresponding information technology. They only stay at the level of accounting, and the management of power companies pays no attention to financial management. The corresponding information technology training was not carried out in time, and the information system was not improved in time. So this makes financial managers less able to use the information system to handle their daily work. 
IV. STRATEGIES FOR PROMOTING THE DEVELOPMENT OF FINANCIAL MANAGEMENT IN ELECTRIC POWER ENTERPRISES

\section{A. Strengthening financial management consciousness, Changing the concept of financial management}

Electric power enterprise managers should correctly handle the relationship between production and operation activities and financial management activities, fully understand the importance of enterprise financial management, and attach importance to the development of enterprise financial management. In order to put the financial management of enterprises in the right place, the management activities of electric enterprises should not be limited to the management of production and operation activities. Meanwhile, electric power enterprise managers should infiltrate financial management into all aspects of corporate governance structure and business activities, and promote the reform of traditional financial management to keep up with the process of market-oriented reform of electric power enterprise system. Of course, enhancing financial management awareness and paying attention to financial management development is not only a matter for the management of power companies, but also for all employees of the company. Researchers and production personnel of power companies cannot deny the value of financial management work and the contribution of financial management personnel to power companies because of the importance of their positions. All employees of enterprises should be equal. The management of power companies should also liberate their own solidified ideas, learn to accept financial management, actively learn management knowledge about financial activities, and apply the knowledge of financial activities management to the daily management activities of power companies. At the same time, Power companies should learn from other industries and learn other industry's advanced financial activities management experience.

\section{B. Strengthening financial management control, Sounding financial management system}

Firstly, establishing financial management control consciousness and strengthening financial management is an inevitable choice for electric power enterprises to take a foothold in the fierce market competition. Managers of electric power enterprises should stick to the concept of fine budget management. By setting up a special financial budget management department, the goal of enterprise budget management should be refined as far as possible, so as to enhance the awareness of budgetary control, strengthen budgetary supervision, and strictly check budgetary slack behavior. Secondly, strengthening the internal control of electric power enterprises. Combined with the actual situation of electric power enterprises, in line with internal control requirements, electric power enterprises should focus on management innovation to set up an internal control system suitable for our enterprises, so as to strengthen the role of internal audit, ensure the authority and relative independence of the internal audit department to ensure the internal audit. Meanwhile, electric power enterprises should strengthen internal supervision. By severely punishing enterprise personnel for their right to seek personal gains and corruption, electric power enterprises should link the performance of employees with salary, and strengthen internal incentives. Electric power enterprises should break down their financial objectives into practical value and non-value indicators. By returning these indicators to the management information system, electric power enterprises should further optimize and upgrade the system, and constantly improves the comprehensive index evaluation ability of the management information system.[4] In the process of system reform of the power industry, we should follow the trend of marketization, step out of the original planned economy, establish a modern corporate governance system, and restrict and balance rights to change the phenomenon that the rights of some of the original power management personnel is so big. Strengthening internal control and internal supervision and establishing a strict evaluation system will enable other employees of the management enterprise to perform their duties with due diligence; at the same time, by strengthen the financial incentive system of the electric power enterprises, employees can actively work for the power enterprise. In addition, power companies should accelerate the progress of enterprise financial information construction, by cooperating with hightech companies outside, improve financial information systems, and hire outside technical personnel to provide information technology training for the current financial management department of power companies, while actively communicate with other power companies, negotiate in order to use a unified information system .And power companies should speed up the informationization of financial information so that it can rescue financial personnel from simple accounting operations. By improving information utilization and integration rate, financial management personnel will have more time that spent on financial decisions, so that financial information transmission can keep up with the development of power companies, and it can also increase the sharing of financial information.

\section{Improving the professional quality of financial management personnel}

In electric power enterprises, the management of enterprises should attach importance to the development of financial managers, and should put financial managers and technicians in the same important position. Firstly, the selection of talents in electric power enterprises should adopt a more open form. Whether external or internal selection, electric power enterprises should pay attention to the comprehensive strength of financial managers, that is, the grasp of financial management knowledge, work ability and so on.[5] In addition, enterprises can regularly train financial management personnel in the electric power industry every year and conduct periodic knowledge lectures, with corresponding examination. Meanwhile, it carries out corresponding examination. Electric power enterprises can cooperate with domestic universities and jointly train professional accountants in electric power enterprises, which enables more and more people to master solid knowledge of financial accounting in the power industry, so as to meet the needs of the power industry for financial accounting. Today, with the rapid development of big data, power companies should keep up with the pace of big data development, pay attention to the information construction of corporate financial 
management departments, and focus on cultivating the ability of financial managers to use information systems for financial work processing. At the same time, power companies should also take advantage of the big data era to develop their own financial information simulation processing system to simulate the daily financial work of the power industry, and encourage financial personnel to operate the simulation system to increase the financial staff's familiarity of the daily business treatment and the proficiency of the operation.

\section{CONCLUSION}

While times are developing, electric power enterprises are also developing. As the core of enterprise management, financial management plays an important role in the sustainable development of electric power enterprises. Electric power enterprises should attach importance to the role of financial management. At the same time, electric power enterprises should establish a scientific and perfect financial management system to give full play to the function of financial management, and then promote the development of the power industry.

\section{REFERENCES}

[1] He Zhangjie, Chen Na, Zhang Genwen, "Problems and Countermeasures of financial management in electric power enterprises", Heilongjiang Science and Technology Information, 2012(1) pp. 86-89(In Chinese)

[2] Huang Limei, "Problems and Countermeasures in current financial management of electric power enterprises", Green economy, 2014 (13):pp. 196-197(In Chinese)

[3] Bao Jingui, "Analysis of problems and Countermeasures in financial management of electric power enterprises", Technological innovation and Application, 2012 (5) p. 248(In Chinese)

[4] Wang Yanfei,"Analysis on innovation of financial management in electric power enterprises", Management Insights, 2012 (10) pp. 140141(In Chinese)

[5] Lindo,"Problems and Countermeasures of financial management in electric power enterprises", urban economy, 2016 (34) p. 53-54(In Chinese) 